\title{
Memories of Captured Song: Exploring Shifting Memories and the Legacies of Music- Making in Chilean Detention Centers through the Cantos Cautivos Testimonial Project
}

\author{
JESSE FREEDMAN
}

\begin{abstract}
This article examines the role and potential of the digital archive project Cantos Cautivos (Captive Songs) in the climate of post-dictatorship memory and reconciliation in contemporary Chile. I argue that the site's flexible and dynamic architecture and its approach to collecting testimonies, which is centered specifically around musical memories, contribute to a dialogic exchange with and critique of state-sponsored memory projects. Through this process, new forms of memory emerge that I describe as "intramemories" and "intermemories," which are products of exchange both within and beyond the project's scope. I draw on case studies of two testimonial "corpora" from two of the archive's most prolific contributors, both of whom composed many songs in detention. With song at its methodological core, I show how this project uniquely contributes to critical conversations in contemporary archival studies around issues of geography, identity, and memory.
\end{abstract}

The musical histories and narratives of mid-century Chilean politics have resulted in an almost mythical quality surrounding many of the key performers and their legacies. ${ }^{1}$ The role of Victor Jara in the campaign and democratic elections of socialist president Salvador Allende, and his brutal assassination at the hands of the Chilean military forces after the coup on September 11, 1973, turned him into a martyr for progressivism and human rights. Groups like Inti-Illimani and Quilapayún, both involved in Allende's Popular Unity (UP) coalition and later forced into exile after the rise of the Augusto Pinochet dictatorship (1973-1990), became international heroes along with dozens of other exiled artists fighting for Chilean solidarity around the globe. These and many other artists involved in the nueva canción (new song) movement have continued to resonate in struggles against fascism and for human rights not only in Chile but around the globe. This music has become part of an official soundtrack that commemorates and testifies to Chilean struggle and resistance.

Frequently absent from this soundtrack and the memories surrounding it are the smaller acts of musical activity by Chilean citizens living under the dictatorship. Tens of thousands of these citizens were imprisoned by the Chilean military, and many wrote and performed music as a means to survive and resist the dictatorship. Over the course of the seventeen-year reign of the Pinochet dictatorship more than 1,100

\footnotetext{
${ }^{1}$ I want to acknowledge the editorial and conceptual support on this piece from Jonathan Ritter and Katia Chornik, who were instrumental at various stages of the article's development. Additionally, I want to thank Sergio Vesely for his time and his instrumental commentary.
} 
detention centers existed across the country. ${ }^{2}$ Of the over 40,000 recorded individuals who fell victim to human rights violations, torture, and detainment, there were 3,197 confirmed fatalities and countless other individuals missing or disappeared. ${ }^{3}$ The musical activity of this group is part of a much larger story often overlooked in histories of music during this era.

The legacies of political detention and torture in Chile have been documented and commemorated through numerous streams at the civil, political, and executive levels. ${ }^{4}$ Following Maria G. Cattell and Jacob J. Climo's discussion on the processual aspects of social memory, the variety of "texts" produced at each of these levels is subject to disjunctures between continuity and forgetting, between reconciliation and healing. ${ }^{5}$ The memories wrapped up within these lieux de mémoire are necessarily incomplete as they serve the commemorative requirements of the individuals, bodies, or spaces that produce them. ${ }^{6}$ Other accounts have deliberately obfuscated the activities or behaviors of individuals connected with political violence, likely regarding circumstances in the production of shame surrounding what Michael Lazzara has explored as "complicity" and "complacency" under the dictatorship. The memorial "products" produced in reaction to the horrors of the dictatorship, whether through individual, public, or state apparatuses, often have not had the infrastructure to communicate with memorial spaces and processes beyond the incompleteness and subjectivity under which they were realized. Though these parameters are necessary in serving the requirements of the actors that produce them, there has been little consideration as to how these incomplete and/or subjective memories communicate with and inform one another, all the while supporting the conditions and perspectives of their respective positions.

One project that offers a space for considering such an exchange of memories is the digital testimonial project Cantos Cautivos (Captive Songs). The project was established in 2015 by ethnomusicologist Katia Chornik and is a product of her postdoctoral research, over a decade of work with former political prisoners, and collaboration with the Museum of Memory and Human Rights in Santiago. Chornik, who is herself the daughter of political prisoners, developed this platform using online crowdsourcing to invite former political prisoners, their families, and their descendants to share elements of their experiences in detention on their own terms, mediated through memories of a song or musical activity. A number of testimonies also come from oral histories delivered in interviews, which were subsequently transcribed for the archive with permission. Chornik argues that "remembering through music, possibly the most subjective and emotional cultural form, enables witnesses to establish

\footnotetext{
${ }^{2}$ The exact number of detention centers is unknown. A total of 1,132 torture and detention centers were recognized in the Comisión Nacional Sobre Prisión Política y Tortura, Informe de la Comisión Nacional sobre Prisión Política y Tortura (2004), 261, https://doi.org/10.38178/cep.vi97.642. However, other sources, such as the website Memoriaviva.com, acknowledge 1,168 centers.

3 This statistic comes from the Cantos Cautivos "Victims" page, accessed May 19, 2021, https://www.cantoscautivos.org/en/victims.php.

${ }^{4}$ Katherine Hite and Cath Collins, "Memorial Fragments, Monumental Silences and Reawakenings in $21^{\text {st }}$-Century Chile," Millennium: Journal of International Studies 38, no. 2 (2009): 380, https://doi.org/10.1177/0305829809347537.

${ }^{5}$ Maria G. Cattell and Jacob J. Climo, "Introduction: Meaning in Social Memory and History: Anthropological Perspectives," in Social Memory and History: Anthropological Perspectives, ed. Jacob J. Climo and Maria G. Cattell, (Walnut Creek, CA: Altamira Press, 2002), 1-36.

${ }^{6}$ Pierre Nora, “Between Memory and History: Les Lieux de Mémoire,” Representations 26 (Spring 1989): 7-24, https://doi.org/10.2307/2928520.

${ }^{7}$ Michael Lazzara, Civil Obedience: Complicity and Complacency in Chile since Pinochet (Madison: University of Wisconsin Press, 2018).
} 
relationships with difficult experiences, facilitating, engaging with and contributing to memory process, and opening up previously closed spaces."

For this article, which is based on nearly two years of personal work with Cantos Cautivos, I consider the ways that testimonies submitted to the project work together with, and productively against, both the "official" memories of the Chilean government and other memories in this virtual archival space. I would like to consider the possibility of intramemories and intermemories as dynamic and manipulable products that emerge out of testimonial and memorial encounters in this digital space. These terms are inspired by the musical metaphor that Jorge Montealegre has drawn upon in his own testimonial practice as the "polyphonic memory" of former political prisoners." The dynamism implicit in this term necessitates a form of interaction and exchange between various forms of memory. ${ }^{10}$ In the case of intramemories, the environment of Cantos Cautivos and the ways in which the site architecture has been constructed lend to spontaneous discovery and connection among users and testimonial providers. Due to its inclusive system for defining whose testimonies are eligible for submission, Cantos Cativos produces a form of memoratic dialogue across Chile's geography and between generations. This internal dynamism of memory within the archive reveals the evolving narration these testimonies produce as they interact with one another. Intermemories refer to the ways that texts within the site, in the form of testimonies and shared musical experiences, have the potential to dialog with other spaces and memory projects outside of the archive itself. Following Diana Taylor's development of embodied memory and its role in transmitting other forms of knowledge, ${ }^{11}$ these memorial structures emerge, shift, and evolve precisely at the limits between individual and institutional commemoration. To examine these constructs, this paper will focus on two "collections" of testimonials provided by the two most prolific contributors to the archive.

After briefly describing the climate of memorialization in post-dictatorship Chile, this article will then discuss the site infrastructure. I go on to analyze the two "corpora" of testimonies from the contributors mentioned above and offer a reflection on how these two individuals contribute to Cantos Cautivos as a space for dynamic and interactive memoratic discourse. Lastly, I will conclude by problematizing any obvious singularization of Cantos Cautivos, instead considering how it simultaneously approaches conceptual aspects of public-facing archive and private testimony, of a fixed platform and flexible digital space. By framing the project within conversations by contemporary digitalarchivists working in "local" and "community-based" archives, it will be positioned within larger critical discussions regarding geography, identity, and methodology in archival praxis. Through this work, I hope to demonstrate how this project, with song at its philosophical and methodological core, offers avenues for dynamic interactions and dialogues between spaces of memory.

\section{Memorializing in Chile Post-Dictatorship}

The process of memorialization and reconciliation in post-dictatorship Chile has been manifold,

\footnotetext{
${ }^{8}$ Katia Chornik, "Memories of Music in Political Detention in Chile under Pinochet," Journal of Latin American Cultural Studies 27, no. 2 (2013): 159, https://doi.org/10.1080/13569325.2018.1450742.

${ }^{9}$ Jorge Montealegre, Derecho a Fuga: Una extraña felicidad compartida, 2nd ed. (Santiago: Editorial Asterión, 2018).

${ }^{10}$ Diana Taylor, The Archive and the Repertoire (Durham, NC: Duke University Press, 2003), 21.

${ }^{11}$ Taylor, Archive and the Repertoire, xviii.
} 
complex, and frequently fraught with challenges and criticism. ${ }^{12}$ This situation is not unique to Chile, as memory and truth and reconciliation projects directed at the state level have suffered from representational and subjective lacunae for decades. Michael Pollak writes of the "underground memories" that mark "the border between the sayable and the un-sayable, the confessable and the un-confessable." ${ }^{13}$ These memories, and their borders, are defined from various, and often competing, interests oriented toward the preservation and active pursuit of a unified and collective memory. ${ }^{14}$ Often, however, such representational memory projects, while purporting to speak and remember on behalf of the collective, can only represent the subjectivity and sources from which they derive and possibly ignore important dimensions of, for example, gendered violence, repression, and memory under dictatorship. ${ }^{15}$

Following the transition to democracy in 1989, president-elect Patricio Alwyn called for the formation of The National Commission for Truth and Reconciliation, chaired by the former senator Raúl Rettig. Between May 1990 and February 1991, the commission documented human rights abuses under the dictatorship in the over 1,000-page document known as the "Rettig Report." This report, however, was widely deemed ineffective and, in many cases, an outright failure, as it did not mention instances of torture against Chilean citizens. To remedy some of these failures, in 2003 President Ricardo Lagos created the Valech Commission to address the circumstances and conditions of political imprisonment and torture under the dictatorship. This commission was carried out from September 2003-June 2005 and produced an even more expansive document than the Rettig Report within its first year. However, at the time of its publication in November 2004, then President Lagos called on the commission to compile over 1,000 additional cases submitted by individuals and families originally left out so that they could seek justice as well as gain eligibility for a 2005 reparations program providing free education, housing, and healthcare. ${ }^{16}$

The then Director of the National Security Archive's Chile Documentation Project Peter Kornbluh acknowledged the complications and uncertainty surrounding the publication of this latter report: "Instead of closure, however, the issuance of the report has fully opened the door to a national dialogue over the crimes of the military dictatorship and those civilian collaborators who facilitated the regime's dirty work." 17 Once the administration undertook the task of administering or reconciling a form of justice denied by an earlier generation within its own ranks, tensions over how best to dispense this justice became a charged and complex issue. In the case of the Chilean military, many soldiers who directly participated in acts of terrorism and violence against Chilean citizens continued (and continue) to have roles in government. Furthermore, in a point importantly addressed by Diego Benegas in his discussion of the escraches ${ }^{18}$ in post-dictatorship

\footnotetext{
${ }^{12}$ Two important English-language texts that examine issues around memorialization in post-dictatorship Chile are Michael Lazzara, Chile in Transition: The Poetics and Politics of Memory (Gainesville: University of Florida Press, 2006) and Steve J. Stern, Reckoning with Pinochet: The Memory Question in Democratic Chile, 1989-2006 (Durham, NC: Duke University Press, 2010), https://doi.org/10.1215/9780822391777.

${ }^{13}$ Michael Pollak, "Memoria, olvido, silencio," in Memoria, Olvido, Silencio: La producción social de identidades frente a situaciones límite, trans. Cristian Gebauer, Renata Olveira Rufino, and Mariana Tello, ed. Ludmila Da Silva Catela (Buenos Aires: Ediciones al Margen, 2006), 24.

${ }^{14}$ See, for example, Elizabeth Jelin's important work on state memory, State Repression and the Labors of Memory, trans. Judy Rein and Marcial Godoy-Anativa (Minneapolis: University of Minnesota Press, 2003).

${ }^{15}$ For valuable discussions on the legacies of gendered violence in state memory, see Jelin, State Repression, especially ch. 6; and Caroline Davidson, "Nunca más meets \#niunamenos-Accountability for Pinochet-era sexual violence in Chile," Columbia Human Rights Law Review 51, no. 2 (2018): 100-182.

16 "Commission of Inquiry: Chile 03," United States Institute of Peace, accessed May 24, 2021, https://www.usip.org/publications/2003/09/commission-inquiry-chile-03.

${ }^{17}$ Peter Kornbluth, "Letter from Chile," The Nation, January 13, 2005, https://archive.globalpolicy.org/intljustice/wanted/2005/0113chileletter.htm.

${ }^{18}$ Publicly orchestrated manifestations for calling out and denouncing perpetrators of political violence.
} 
Argentina, he argues that reconciliation as "[t]he frequent tactic in human rights, of insisting on remembrance, had already been neutralized by the rhetoric of national reconciliation, itself a post-traumatic formation, that in the name of the collective urged the country to 'forgive and forget' in order for it to 'recover' from its 'painful' past." 19 By assuming responsibility for reconciliation projects without bringing justice to perpetrators of violence, post-dictatorship governments assume ownership of "collective trauma" and maintain an inscription of traumatic habitus in the public. ${ }^{20}$ As calls for greater accountability and visibility into the crimes of past perpetrators became more pronounced, the Lagos administration could not keep up with the plurality and complexity of demands from citizens who were either survivors of political violence or family members of those survivors.

Through this process, Chile saw a more diverse range of memory spaces and products alongside those directed at the political and executive levels. One such example is the Parque por la Paz (Park for Peace) at Villa Grimaldi. Located on the eastern outskirts of Santiago in the commune of Peñalolén, Villa Grimaldi was one of the most violent torture and detention centers during the dictatorship. It opened to the public in 1994, and in 1997 the Park for Peace was officially registered as an International Site of Consciousness (Cantos Cautivos is also recognized as an International Site of Consciousness). The park is recognized as one of the best examples of a "community-controlled collective," but it was frequently at the heart of complicated and fraught conversations among survivors regarding the appropriate way to commemorate unspeakable state violence. ${ }^{21}$ An alternative example would be the Museo de la Memoria y los Derechos Humanos (Museum of Memory and Human Rights), which was inaugurated in 2010 by the administration under former President Michelle Bachelet (herself a survivor both of torture and detention at Villa Grimaldi and of political exile during the years of the dictatorship). While both institutions are committed to the preservation of memories and the advancement of human rights, Villa Grimaldi foregrounds the role of community members in their mission, while the museum more openly acknowledges its conceptual foundations in government-directed projects such as the Rettig Report and the policies of the Lagos administration. ${ }^{22}$ While neither of these positions is objectively more, or less, effective at the promotion of human rights-centered policies, tensions both within and between these institutions underscore one prominent aspect of memory work in post-dictatorship Chile.

In efforts to speak about the horrors of torture and imprisonment under the dictatorship that had been up to that point (at least publicly) unspeakable, a particular subject position denoting violence and suffering became a kind of political imperative. This framing was critical in exposing these horrors to a wider Chilean public, as well as putting pressure on the Lagos administration, which was recalcitrant in its public condemnations of military and government officials involved with torture and imprisonment. However, in its effort to expose the most vile aspects of human suffering, the report constructed an "official" form of collective memory as well as a system for participation in a particular memoratic discourse. Within the diversity of experiences of Chileans in detention were moments of hope, creation, and resistance, in addition

\footnotetext{
${ }^{19}$ Diego Benegas, “'If There's No Justice...': Trauma and Identity in Post-Dictatorship Argentina,” Performance Research 16, no. 2 (2011): 23, https://doi.org/10.1080/13528165.2011.561671.

${ }^{20}$ See Benegas, "Trauma and Identity," 20-21; see also Claire Moon, "Healing Past Violence: Traumatic Assumptions and Therapeutic Interventions in War and Reconciliation," Journal of Human Rights 8, no 1 (2009), https://doi.org/10.1080/14754830902717726.

${ }^{21}$ Peter Read and Marivic Wyndham, Narrow but Endlessly Deep: The Struggle for Memorialisation in Chile since the Transition to Democracy (Acton, ACT: Australian National University Press, 2016), 129-131, https://doi.org/10.22459/NBED.06.2016.

${ }^{22}$ Available at https://web.museodelamemoria.cl/sobre-el-museo/\#menu6.
} 
to abject horror and suffering. While official projects foreground particular experiences with respect to the construction of a notion such as "victimhood," other projects cultivate a less circumscribed approach to participation in the sharing and working through of memories. ${ }^{23}$ Cantos Cautivos is one such project that facilitates a more expansive consideration beyond trauma and victimhood, giving participants space to testify and experience empowerment in the wake of difficult memories.

\section{Cantos Cautivos}

Cantos Cautivos was conceptualized by Katia Chornik and released as an active website in 2015. Initially a product of her postdoctoral research, the project has, in several ways, assumed an autonomous identity through the freedom of contribution and access afforded to individuals contributing testimonies. The website infrastructure was designed by Hernán Theiler, who was a young boy in Chile at the time of the military dictatorship. As will be demonstrated, Theiler's architecture facilitates spontaneous and unexpected connections between the music and testimonies. This encourages a form of commemoration that is both highly personal, and highly networked, allowing former political prisoners submitting testimonies and younger generations of site users, with or without connection to political violence, to realize alternate narratives of Chilean history. Both users and contributors, following Diana Taylor's own reflection during a series of visits to the Villa Grimaldi Peace Park, become involved in a complex form of witnessing, becoming "both the subject and the product of [one's] acts." ${ }^{24}$ However, whereas Taylor's observationsappropriately-address the contemporaneity of the performative dimensions of a kind of "trauma paradigm," Cantos Cautivos, in its invitation to memories not solely rooted in trauma, fosters a kind witness(ing) with the potential to move across time and geography.

Presently, there are 155 testimonies, of which 52 discuss songs composed fully or partially in detention. The individual and singular testimonies from many of the other participants in this project document a breadth of memories, ranging from moments of hope and beauty to some of the darkest and most painful memories that the courageous participants have ever shared. Contributors are provided with multiple options within which they can participate and identify with the project. The "Share Your Memories" tab directs visitors to a simple web form that encourages individuals to think much more expansively about the role of music in detention than has potentially been historically encouraged.

\footnotetext{
${ }^{23}$ Antonio Traverso, "Dictatorship Memories: Working through Trauma in Chilean Post-Dictatorship Documentary," Continuum 24, no. 1 (2010): 180-182, https://doi.org/10.1080/10304310903444037.

${ }^{24}$ This digital project is not dated but can be found at section 1.2, "Trauma as Durational Performance": Diana Taylor, Villa Grimaldi, accessed May 25, 2021, http://villagrimaldi.typefold.com.
} 


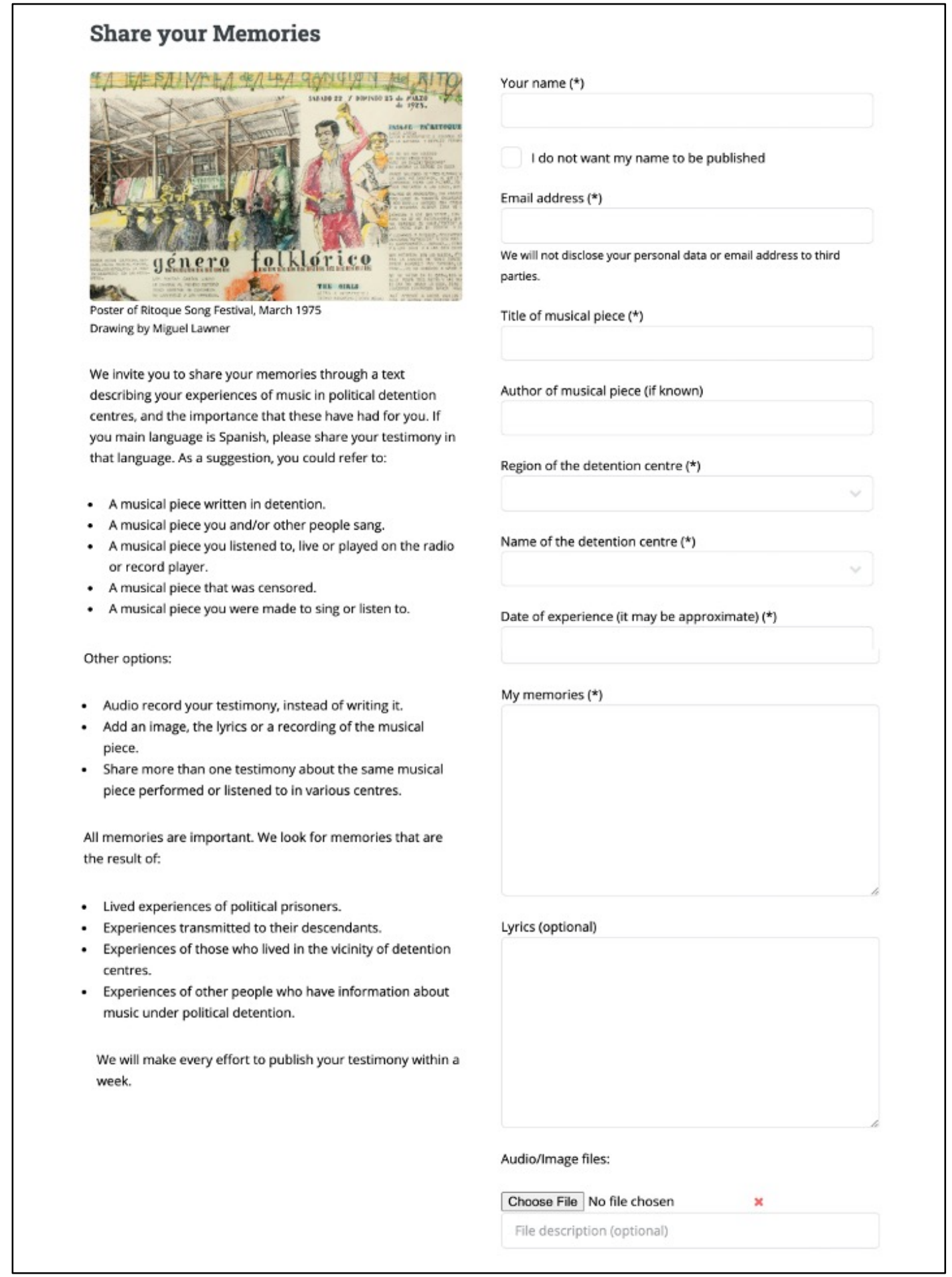

Figure 1: Screen capture of the "Share your Memories" tab on the Cantos Cautivos website.

Mahmood Mamdani has examined the destructiveness of terms such as "gross violations" and "severe ill-treatment" in the South African Truth and Reconciliation Commission and the ways these terms obfuscated structural violence and oppression during the Apartheid era. ${ }^{25}$ The circumstances surrounding

${ }^{25}$ Mahmood Mamdani, "Amnesty or Impunity? A Preliminary Critique of the Report of the Truth and Reconciliation Commission of South Africa (TRC)," Diacritics 32, nos. 3/4 (2002): 36-42, https://doi.org/10.1353/dia.2005.0005. 
memory and testimonial commissions in Chile, though not subject to the same terminological issues as in the South African case, resulted in a similar foregrounding of physical violence and torture. In the Cantos Cautivos archive, although many testimonies approach painful memories, many reflect more quotidian aspects of musical life, moments of celebration, and acts of resistance. This expansive approach eliminates any type of hierarchization or emphasis on traumatic "value." Furthermore, Cantos Cautivos directly invites family members and descendants as well as individuals who may have lived in proximity to detention centers. This valuation of a plurality of contributing voices extends the scope and impact of the project to invite consideration and reflection among a wider community.

While the project does not attempt to privilege one form of testimony over another, certain criteria are required in order to submit a testimony. In addition to the contributor's name (the option exists to submit anonymously), the user provides the song title and testimony. One notable criterion on the "Submit Your Memories" page is the detention center and region in which the memory took place. The project recognizes an important geographic element to the testimonies and integrates this information in a way that facilitates wider networking and a sense of connection. With more than 1,100 centers for torture and detention, imprisonment in Chile under the Pinochet dictatorship was pursued as a veritable industry. As of May 2021, the Cantos Cautivos project has testimonies from thirty-eight detention centers in eleven of Chile's sixteen geographic regions. Many individuals were transported through multiple sites over the course of their detention, and their experiences accrued markers of the geographic regions they moved through. Visitors to the site are encouraged to explore the "Detention Centers" page, where they can move through either a set of links to pages with information about individual centers or a Google Map with pins for each of the centers.

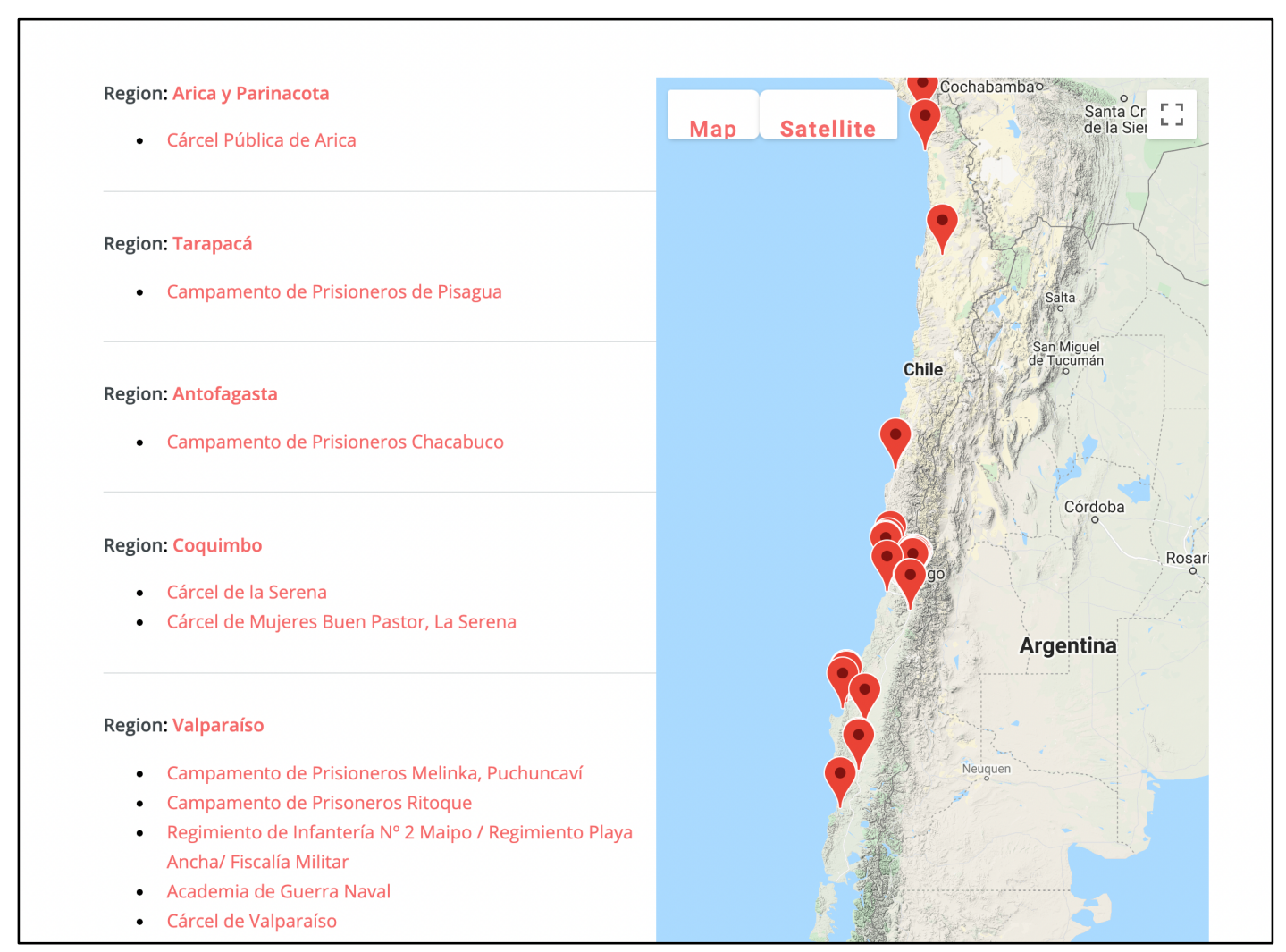

Figure 2: Screen capture of the "Detention Centers" page on the Cantos Cautivos website. 
These pages have a link to an interactive webpage on the detention center on the website for the Museum of Memory and Human Rights in Santiago. Lastly, each page features all the testimonies that were based on a particular site. Through this function, the user can approach a "collection" of testimonies unified through geography, thereby realizing connections between otherwise disparate-seeming testimonies and producing a more complex sonic picture of a particular site.

This last point reveals possibly the most significant functionality of the project: the ability to link testimonies through terms, musical artists, detention centers, and other textual identifiers. The central component of the project is the "Testimonies" page.

\section{Testimonies}

Testimonies are sorted by publication date, showing the newest first.

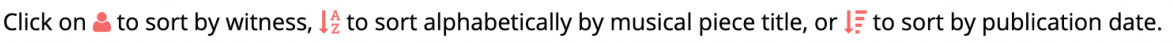

a $\perp_{Z}^{\mathrm{A}} \downarrow \equiv$

King Ñaca Ñaca (El rey Ñaca Ñaca)

Music piece by: Sergio Vesely

Testimony by: Renato Alvarado Vidal

Experience in: $\quad$ Campamento de Prisioneros Melinka, Puchuncaví, May - October 1975

Tags: $\quad$ Renato Alvarado Vidal Sergio Vesely Campamento de Prisioneros Melinka, Puchuncaví Valparaíso

El rey Ñaca Ñaca King Ñaca Ñaca

"During the last third of the 20th century, the concentration camps of the Chilean dictatorship were characterised by a high grade of

organisation among prisoners, as well as the overflowing creativity they applied to all areas of human ingenuity. ”

[Read full testimony]

Published on: 26 April 2020

Figure 3: Screen capture of the "Testimonies" page on the Cantos Cautivos website.

Simply clicking on the "Testimonies" tab will navigate the user to a list of testimonies beginning with the most recent and going back to the oldest. Each testimony "preview" is titled according to the song commemorated in the text. There is a listing for the composer and/or artist, the individual providing the testimony, the detention site and year, as well as a number of "tags" marking important information. Lastly, there is a brief excerpt of the testimony highlighting the first few sentences of text. If terms are searched via the search bar at the top of the window, they will be highlighted in the text excerpt.

There are then several avenues to navigate through the testimonies and identify trends and/or connections. In addition to links taking the user through the detention center page, the tags are an extremely effective way to identify important individuals, geographic locations, and musical terms. By clicking on one of the tags, the user is presented with a new list of testimonies organized according to the term. For terms or phrases that are not tagged, the user can simply input that text into the search bar and produce a new list of results. 
Within the testimonies themselves, certain terms have been tagged in both Spanish and English to produce a small pop-up window with a definition.

\section{A Cocky Fellow (El puntúo)}

Music piece Víctor Canto and Luis Cifuentes (lyrics),

by: Roberto Parra (music)

Testimony

Luis Cifuentes Seves

Music genre (usually for

voice and

pamento de Prisioneros Chacabuco,

accompaniment) and

ember 1973 - February 1974

partner dance, found in

Chile, Argentina and

Bolivia.

This cueca was composed in Chacabuco between November 1973 and February 1974, and was sung by the band Los de Chacabuco, to which Víctor Canto and I belonged.

Figure 4: Screen capture of an example of a tagged term, with its definition appearing in a pop-up window, on the "Testimonies" page on the Cantos Cautivos website.

These simple definitions are designed to be accessible on desktop and mobile platforms and highlight terms that may be unfamiliar to individuals without a background or connection to the social and political circumstances of detention under the Chilean dictatorship. Political terms such as MIR (Movimiento de Izquierda Revolucionaria; Revolutionary Left Movement) or DINA (Dirección de Inteligencia Nacional; National Intelligence Directorate), musical genres (e.g., bolero and zamba), and additional terms pertaining to geography, Chilean slang, and other topics are all included to invite individuals with differing levels of connection to Chilean political history to participate in this memory space. These terms can be further searched to identify all the testimonies that reference them, thereby establishing a new network of connections.

It has been important to examine some of the website's functionality and the strategies for interacting with it for several reasons. Principally, the infrastructure reflects the broader methodology behind this testimonial site, who is eligible to participate in it, and the criteria structuring that manner of interaction. Chornik has observed elsewhere in her interviews about musical memories with a former agent of the Chilean secret police force under Pinochet (DINA) ${ }^{26}$ that the interviewee in this context frequently switched between present and past tense and first and third person in these testimonies, thereby signaling a complex

\footnotetext{
${ }^{26}$ The Cantos Cautivos team decided not to include testimonies or interview materials from former agents of torture and detention centers in the archive. See Katia Chornik, "Music and Torture in Chilean Detention Centers: Conversations with an Ex-Agent of Pinochet's Secret Police," Journal of Latin American Cultural Studies 27, no. 2 (2013): 157-173.
} 
and fragmented sense of memory and identity with regards to, in this case, the administration of torture. In other testimonies from prisoners, we can see a similar sense of musical and personal identity disaggregated across a plurality of experiences and geographies. The musical centering of these testimonies, therefore, seems to produce a subject simultaneously individual and decentered, one that remembers within and against the memories of others.

In this way, the site infrastructure facilitates the production of what I am here describing as intramemories and intermemories. The first, and more obvious, entails the networking of memories from those that contribute testimonies to the platform. By the nature of the submission platform, contributors are necessarily brought into a form of interaction with testimonies bearing some form of connection to their own. These connections can result in stimulating forgotten memories, reconnecting with individuals that contributors knew in detention, or even the reframing of memories thought to be fixed (indeed, there are instances in the project of two differing testimonies recalling the same experience). On the other side, the project produces intermemories resulting from an exchange between political and official projects with individual memories. Site users with secondary or limited connection to the years of the dictatorship obtain a new lens through which to view the government discourse around memory and reconciliation in Chile and may be able to exercise a more critical perspective when evaluating the official silencing around the legacies of the dictatorship in contemporary Chilean politics. ${ }^{27}$

In addition to fostering and supporting the sharing of vulnerable and traumatic memories among members of this community, the project brings in critical individual perspectives on the role of the arts in trauma and healing that may otherwise be seen as peripheral or marginal to discussions within government organizations regarding truth and reconciliation projects. As Chornik has noted, in the context of commissions documenting records of abuse and human rights violations under the dictatorship, musical memories have often been subject to a form of self-censorship, as they were not deemed consequential in comparison with more direct testimonies of violence and torture. ${ }^{28}$ In this way, the project considers acts of music making in detention and the retrospective framing of these activities within a broader nexus of interand intra-memoratic intersections between individual and institutional subjectivities. Cantos Cautivos' expansive and inclusive approach to testimonial authenticity fosters a wider diffusion of testimonial agency than if testimonies were subject to more rigid criteria.

In instances where music does enter into conversations around memorializing the period of the Chilean dictatorship, the discussion almost always centers on the artists involved in the political song movement known as nueva canción. The movement drew broadly from various traditional, folkloric, and popular musics and was diffuse in many countries throughout the Spanish-speaking Americas and Brazil in the 1960s and 1970s. In Chile, nueva canción was closely aligned with Allende's Popular Unity government and was often characterized by polyphonic singing and the use of Indigenous instruments like the quena (end-blown flute), zampoñas (panflutes), and the charango (small stringed instrument traditionally made from armadillo shell). In addition to groups like Inti-Illimani and Quilapayún were Aparcoa, Illapu, and a host of others, the majority of whom fled Chile due to the movement's officially subversive status under the dictatorship. Other artists in the nueva canción movement were more closely aligned with the cantautor (singer-songwriter) tradition of artists like Rolando Alarcón and Violeta Parra and performed solo and

\footnotetext{
${ }^{27}$ Carolina Aguilera and Gonzalo Cáceres, "Signs of State Terrorism in Post-Authoritarian Santiago: Memories and Memorialization in Chile," Dissidences: Hispanic Journal of Theory and Criticism 4, no. 8 (2012): article 7, https://digitalcommons.bowdoin.edu/dissidences/vol4/iss8/7.

${ }^{28}$ Katia Chornik in discussion with the author, February 2021.
} 
typically with guitar. Victor Jara and Patricio Manns were some of the most influential cantautors in the nueva canción movement

Much in the same way that testimonies aligning with political narratives of torture and detention have circulated with the greatest "memoratic currency" in post-dictatorship Chile, the less frequent musical narratives framing the experiences of political prisoners are almost always depicted alongside the "revolutionary" attributes of nueva canción artists. ${ }^{29}$ This mainstream narrativizing of Chilean political music, centering around some of these more well-known individuals and ensembles, tends to dominate smaller acts of music-making and resistance. While nueva canción artists are, indeed, represented many times in the archive as sources of inspiration and hope for many Chileans in detention, one of the greatest values of the Cantos Cautivos archive is that it offers a more expansive, individuated, and less mediated presentation of the critical circulation of music and musical activity in detention.

\section{Two Testimonial Corpora: Luis Cifuentes}

Luis Cifuentes Seves was a member of the ensemble Los de Chacabuco, which was established and directed by Ángel Parra, son of the renowned folklorist and cantautora Violeta Parra, in the Chacabuco Prison Camp in the Atacama Desert. Chacabuco functioned as a detention site between November 1973 and April 1975. After his initial detention at the National Stadium, Cifuentes was transferred to Chacabuco, where he was imprisoned without charges until he was exiled to the United Kingdom for ten years. He earned his doctorate in material science at the University of Manchester, and after returning to Chile, he was appointed as faculty at the University of Chile in the Department of Physical and Mathematical Sciences. In addition to his scientific work, he has written and published prolifically in the arts, humanities, and history of student movements in the Chilean university system.

Chacabuco, which was occupied only by men, has been written about in several spaces with regard to the complex civic, educational, and creative infrastructure created by the prisoners. ${ }^{30}$ In addition to musical activities, academic courses were taught, comedic groups performed, and an organization known as the Council of Elders (Consejo de Ancianos) was established through a democratic vote to decide on issues pertaining to life in the prison. Tesche and González have identified this form of communal engagement and organization as a form of resistance, which in their framing derives from the distinction between the German terms Resistenz and Widerstand: the former encompassing "passive and private" forms of action and the latter designating "public action." 31 Their work suggests that a key element for this model of resistance developed as a product of the reconfiguration of space through group participation and collective action.

\footnotetext{
${ }^{29}$ The literature on nueva canción is vast, but several key resources on the history of the movement as well as discussion of its "revolutionary" character can be found in: Eduardo Carrasco, La Nueva Canción en América Latina (Santiago: CENECA, 1982); Jan Fairley, "La Nueva Canción Latinoamericana," Bulletin of Latin American Research 3, no. 2 (1984): 107-115, https://doi.org/10.2307/3338257; Juan Pablo González, Oscar Ohlsen, and Claudio Rolle, Historia social de la música popular en Chile, 1950-1970 (Santiago: Ediciones Universidad Católica de Chile, 2009); and Patrice McSherry, "The Political Impact of Chilean New Song in Exile," Latin American Perspectives 44, no. 5 (2016): 13-29, https://doi.org/10.1177/0094582X16683374.

${ }^{30}$ See: Vikki Bell, "Entwined Tellings and the Fragility of the Unique: Relating Narratives of Detention and Survival in Pinochet's Chile," Third Text 32, no. 1 (2018): 125-149, https://doi.org/10.1080/09528822.2018.1459111; Jorge Montealegre, Derecho a Fuga: Una extraña felicidad compartida, 2nd ed. (Santiago: Editorial Asterión, 2019); Paula Tesche Roa and Javier González Alarcòn, "Resistencia política en la oficina salitrera de Chacabuco (1973-1975), región de Antofagasta, Chile," Historia y Memoria 19 (2019): 309-344, https://doi.org/10.19053/20275137.n19.2019.9200.

${ }^{31}$ Tesche and González, "Chacabuco," 319.
} 
It is therefore notable that within the nineteen testimonies provided by Cifuentes referencing the music of Los de Chacabuco, there is not only a general absence of a first-person "I" pronoun—unless framed in relation to a more collective "we" - but that his testimonies frequently highlight the music as part of a collective and in connection to the activities and responses of his fellow prisoners. In his 2020 autobiographical work, Dilo, antes que sea demasiado tarde (Say it before it's too late), Cifuentes moves about his memories through first-, second-, and third-person subject positions as Julio (the name for Cifuentes's pseudonym in the book) passes further into what the author calls the "abyss." By the time of his arrival in the camp as a member of Los de Chacabuco, Cifuentes is no longer the "I" who wakes up (in the present tense) on September 11, 1973, but appears in the third person (past tense), as Julio, a member of a greater collective:

Julio joined as a percussionist and charango player owing to his previous musical experience, even though his skills were not at the professional level. 'Los de Chacabuco' had considerable success among the prison population, achieving in some cases to affirm themselves as superior to famous Chilean folklore groups. Of course, this is an exaggeration, but it contributed to forming a sense of chacabucana identity. ${ }^{32}$

Here Cifuentes underscores a central conceptual and methodological aspect of Cantos Cautivos: that remembering through music facilitates access to memories and spaces of memory that may otherwise be too difficult to approach through other forms of testimonial practice.

Cifuentes's testimonies are typically short and could be described as "direct," but taken as a kind of "corpus," these testimonies chronicle a profound history of music making and resistance under brutal conditions and provide critical insight into the communal activities among the men in this group. As in Dilo, antes que sea demasiado tarde, the testimonies mark a shift in the language surrounding memory between his initial period of detention in the Chilean National Stadium and his detention at Chacabuco. His testimonies from his period at the stadium accompany English-language songs such as "Morning Has Broken" by Cat Stevens and "Answer Me" by Frankie Laine. Through these testimonies, he articulates a positionality of solo performance or listening, one that gives an impression of feeling alone and disconnected in the early days of his detention.

Somewhat conversely, the majority of his testimonies from his period in Chacabuco accompany songs that were made clandestinely through a tape recorder hidden under the performance stage during a 1974 concert by Alberto Corvalán Castillo, who was the son of the former secretary general of the Chilean Communist Party, along with two other prisoners, Guillermo Orrego and Domingo Chávez. This recording was subsequently smuggled out of the prison by Ángel Parra and released on the DICAP label in Paris in 1975. Cifuentes is clear to celebrate the achievements and role of his compañeros and the collective activity involved in bringing this musical history to life, a musical history which his testimonies narrate and annotate.

In this way, Cifuentes's testimonies mark a history experienced both as an individual and as a community. Each entry highlights the collective action of the members of the group with different shades or details incorporated either through his own text or musical texts composed by other prisoners. They commemorate the disappearance and torture of fellow prisoners, the role of religious songs within the social fabric of the camp, and the songs themselves as dynamic and living artifacts of creative activity. Two notable examples are cuecas, a traditional dance form inaugurated as Chile's official dance under Pinochet. The

\footnotetext{
${ }^{32}$ Text is non-paginated, but the reference is available in the section "Sobrevivientes del abismo (Chacabuco)": Luis Cifuentes Seves, Dilo, antes que sea demasiado tarde (Santiago: Editorial Cuarto, 2020).
} 
cueca lost favor with the Chilean public during this period, particularly with those on the Left, due to its promotion by the dictatorship. Its performance by prisoners would therefore carry a sense of irony and resignification in this context. The fact that it is used in a critical capacity and also as a means for supporting communal activities underscores Laura Jordán Gonzalez's discussion of the dance and its multifaceted signification and development, particularly in the nueva canción movement. ${ }^{33}$ Consequently, its role here can be seen as a part of the wider international negotiations and reconfiguring of the cueca's importance as an index for Chilean national identity during the dictatorship. "El suertúo"(Lucky Devil) and "El Puntúo" (A Cocky Fellow) were two cuecas on this clandestine recording for which Cifuentes provided testimonies. We hear the prisoners laughing at the highly coded language required to stay under the radar of the guards present at these public concerts. References are made to camp infrastructure like the "tank," which was sometimes pointed at prisoners while they were having lunch, or the "plaza" where prisoners were supervised while looking for firewood. Other references to the "supplies store" or the "kitchen crew" would have been easily recognizable by the prisoners as elements of daily life in prison presented here in a satirical characterization. In "El puntúo"the lyrics tell the story of a foolish and ignorant prisoner who describes all of the success he has experienced while in Chacabuco:

"El puntúo"(A Cocky Fellow)

I came to Chacabuco cuz I'm such a good person

that's good, said my old man

so you get to see the area

So I came to Chacabuco.

On the airplane, I came

like a puppet

although they didn't serve me

a dry Martini.

A dry Martini, oh yes

not that I was about to escape

but they wouldn't let me

climb on the tank.

Climb on the tank, oh yes, don't know what's going on, they say I'm hauling with me the entire plaza.

The entire plaza, oh yes

it shouldn't surprise you

let's try a bit harder

with the parcels.

With the parcels, oh yes

I'm looking my best for the mayor

\footnotetext{
${ }^{33}$ Laura Jordán Gonzalez, "Chilean New Song's cueca larga," in The Militant Song Movement in Latin America: Chile, Uruguay, and Argentina, ed. Pablo Vila (Plymouth, UK: Lexington Books, 2014), 71-96.
} 
at home I've already got

almost ten buckets.

Almost ten buckets, oh yes

who would have said it

I've already got perks

at the supplies store.

At the supplies store, oh yes

don't get scared of me

I've already made friends

with the commander.

With the commander, oh yes

don't you get too excited

because I'm one of the judges

on the committees.

Let's get cracking, I'm getting plump

I'm with the kitchen crew now. ${ }^{34}$

The audience on the recording erupts with laughter at several of these coded lyrics. Through the group production of these lyrics, the songs on this recording produced a form of collective restructuring of social, political, and artistic life within the camp. Through Cifuentes's community-oriented memorialization of these songs, his memories are brought into dialogue with the other musical memories in the archive as well as those entering from outside of it.

\section{Two Testimonial Corpora: Sergio Vesely}

The other testimonial "set" that warrants a brief discussion in this context was provided by the singersongwriter and visual artist Sergio Vesely. Of the 155 testimonies within the archive, 25 were provided by Vesely referencing his own compositions created in prison. These testimonies and their corresponding songs trace an equally incredible and terrible journey of his passage through seven different detention centers over the course of twenty-two months before his forced exile to Germany in 1976, where he continues to live today. He has cultivated an identity throughout his life as a truly multifaceted and holistic artist. In addition to an active career as a performing musician in Germany, he has developed a number of mural and outreach projects with school children in Germany and has frequently been invited to speak on the topic of human rights in various spaces.

Vesely's relationship to his musical activity in prison demonstrates a distinct form of memorializing. Whereas Cifuentes's testimonies appear to foreground the collective and communal aspects of musicmaking in Chacabuco, Vesely's describe an artistic formation that is more observational and independent. However, nearly all of his songs composed in prison, as well as the testimonies accompanying them, point to an individual, a group, or a collective action that framed his experience and musical development. As the

\footnotetext{
${ }^{34}$ Lyrics by Víctor Canto and Luis Cifuentes, English translation taken from "A Cocky Fellow," Cantos Cautivos, last modified December 14, 2014, https://www.cantoscautivos.org/en/testimony.php?query=10655.
} 
title of his 1986 album, Documento, suggests, these songs, and their narrative presence as a corpus of texts, exist as a kind of sub-archive within the larger project. Whether commemorating the death of a stray dog adopted by prisoners in the camp at Punchuncaví, a conversation with a cellmate, or a friend who helped him to imagine ways to mentally escape from the quotidian life in detention, these songs are snapshots into often ephemeral moments of both triumph and despair. The unspeakability of these moments becomes legible through his testimonial framing while offering a cohesive and unique insight into the conditions of detention experienced by contributors to the platform.

Although he gained a strong musical foundation as a boy in a familial and social context, he truly became a composer in detention as a means to document, mentally escape from, and make sense of his experience. Referring to his musical development in detention, he states, "I discovered in the depths a basic thing. In prison I discovered it as songs. I discovered that I was a person that wanted to sing. And it also came to me: to write songs. Because what I wanted to sing was something that was in me. I didn't want to sing the songs of others." 35 This last point is significant with regard to Sergio's artistic identity: although previously a member of the group Movimiento de Izquierda Revolucionaria (MIR), he is quick to distance himself and his music from the "political" or "propagandistic" (panfletaria). Due to the close association of the nueva canción movement with Allende's UP coalition, they indexed—for many-a very specific form of political participation somewhat bound by a system of imagined partisan strictures. Vesely's music should not be considered apolitical or anti-political; instead, it may be viewed along similar lines with the forms of exchange between different memory spaces encouraged by the Cantos Cautivos project; his songs place his own political ideology and growth into conversation with other forms of political and musical activity. In this way, his compositions mark a kind of departure from the, at least, ostensible mainstream narrativizing that the prisoners were all "leftist militants" sustained through political anthems such as Sergio Ortega's "Venceremos" (We Shall Overcome). Songs such as "Cueca punteada de un solidario" (A Finger-Picked Cueca from a Solidarity Companion) and "Reflexiones" (Reflections) acknowledge and reflect on his political past and conflicts within leftist ideologies. In his testimony accompanying the former song, he states:

If the political constellation of the inmates was explosive, life inside a cell could become a psychological torment as bad or worse than the physical torture. Sectarianism and mistrust were common, and there were only a few people with whom one could talk about personal issues, without fearing that the whole party would know about it the next day. Weaknesses were not tolerated. I wrote this song while at Camp Melinka, thinking openly about our flaws. Thinking about the double standards that ruled our daily behavior: talking about love on one hand and feeding hatred on the other. Thinking about how far we were from living what we preached every day: to live together in equality, in peace, in brotherhood and in solidarity with everyone. ${ }^{36}$

This point, along with many of the other songs from the Documento album (all of which are included on the site), presents a much more complex view of Chilean leftist politics after the coup. The dictatorship touched the lives of every Chilean citizen that lived through it, and in Vesely's inclusive and poetic language, centering on what he describes as a "human condition" (temas bien humanos), he attempts to cultivate a space for wider participation and engagement with issues of memory and human rights without establishing

\footnotetext{
${ }^{35}$ Sergio Vesely in personal communication with the author, November 2020.

${ }^{36}$ This quote comes from Vesely's published testimony on the Cantos Cautivos website: Sergio Vesely, "A Finger-Picked Cueca from a Solidary Companion," Cantos Cautivos, last modified September 23, 2015, https://www.cantoscautivos.org/en/testimony.php?query=10752.
} 
a criterion for party affiliation. He is deeply aware of this potential for his songs to work across rifts in memory and develop connections over conflict:

The result is that these testimonies, I believe, in the future can open like a window to students and people who are interested in this phenomenon. And that they will discover through this window that there was more than pure ideology. That there was more than that political battle. That there was a cantautor that was concerned to sing about a human condition (temas bien humanos). Without giving an ideological undercurrent to everything that he was writing. ${ }^{37}$

Vesely's songs are filled with wit, tongue-in-cheek humor, and fantasy. They articulate the life of a man deliberately searching for and creating meaning and identity under senseless and dehumanizing conditions. One of his most powerful songs is titled "El rey negro" (The Black King), which he wrote to commemorate the birth of a baby girl one night in the camp at Punchuncaví. Vesely presented the lyrics of "El rey negro" to the baby's mother the following morning and the song was premiered in the camp a week later for both prisoners and soldiers. Although cryptic, the lyrics tell of a benevolent king who ruled over his people with kindness. At the end of the song, the narrator is in tears due to the king's disappearance, but the suggestion is that this child will bring a sense of hope in the form of the king.

"El rey negro"(The Black King)

A true story

my son, I'm about to tell you.

A long time ago

there was a black king in the land.

He lived next to a well

and his house was made of mud

he was the people's friend,

they were all like his brothers.

[Chorus]

The sun shined on every tree

there were shepherds and oxen

there was music in the wind

there was music in the wind

in the times of the black King.

His Crown was made of tin

and his beard of chocolate,

he wore a seashell for a shoe

and his hair was of straw.

He never wanted wealth

nor did he ever command his countrymen,

he was kind because he was good

and people respected him

\footnotetext{
${ }^{37}$ Vesely in personal communication with the author, November 2020.
} 


\author{
[Chorus] \\ His kingdom had no laws \\ he ruled freely, \\ working in the mornings \\ and meditating in the afternoon. \\ He invented a game for the children \\ they held hands \\ no one could dominate them, \\ that's what his kingdom was like. \\ [Chorus] \\ My son, I am so sad, \\ the black king vanished \\ I haven't seen him in a long time \\ ever since the day I grew up. \\ Now you shall go out to search for him, \\ you'll tell him I remember him, \\ that I carry him in my suitcase, \\ you'll tell him that I'm in tears. ${ }^{38}$
}

\title{
Conclusion
}

Two terms that have assumed an increasing degree of traction in critical archival studies are "local" and "community-based." These terms are presented as an important counterpoint to the state and institutional archives that have a much more ubiquitous presence in day-to-day perceptions of memory preservation. Cantos Cautivos approaches considerations that are marked by the conceptual framing of these two terms, but the project necessarily, and following Jarrett M. Drake's critique of these terms' lack of "radically precise and politically liberatory language," 39 goes beyond these conceptual limitations. In the case of the "local," the project team (of which I am a member) and the advisory board are currently based all around the world, and many of the testimony contributors have remained abroad since the years of the dictatorship. While geography - and local geography in particular-play a crucial role in cultivating intramemories between former political prisoners participating in the space of the website, the geographic expansiveness of this project and the people involved in it support the more complex conditions for intermemoratic dialogue. Similarly, Drake critiques the notion of "community-based," noting that "community" - presented as such-tends to reify a communal identity or preoccupation in institutional archives, thereby undermining the political impact that a counter-memory project might affect. Without suggesting an elision here between Drake's archival work documenting police violence in Cleveland, Ohio,

\footnotetext{
${ }^{38}$ Lyrics by Sergio Vesely, English translation taken from "The Black King," Cantos Cautivos, last modified September 23, 2015, https://www.cantoscautivos.org/en/testimony.php?query=10644.

${ }^{39}$ Jarrett M. Drake, “Seismic Shifts: On Archival Fact and Fictions,” Medium, August 20, 2018, https://medium.com/community-archives/seismic-shifts-on-archival-fact-and-fictions-6db4d5c655ae.
} 
and Chornik's and the rest of the Cantos Cautivos team's work documenting music in detention during the Chilean military dictatorship, both spaces afford participants the opportunity to discover and identify connections without delimiting the conditions and criteria of testimonial access.

Cantos Cautivos is an incomplete and subjective space of memory. People participating in it—both as contributors and users-do not necessarily consider themselves a "community." However, participants can produce and identify community (if only briefly) through a song, a location, a name, or a term. The project is not a community-based antagonist to state memory, but rather a fluid exchange between individuals and groups at various levels of social, institutional, and national organization. Instead of orienting a sense of community around a condition such as trauma or violence, the archive encourages a dynamic and manifold sense of community. These complex configurations, orchestrated around music, memory, and testimonial practice, encourage unexpected virtual processes of identification and community participation. According to Andrew Flinn, Mary Stevens, and Elizabeth Shepard, "A community, in short, is any group of people who come together and present themselves as such, and a 'community archive' is the product of their attempts to document the history of their commonality." ${ }^{40}$ The legacies of the dictatorship continue to touch the lives of everyone who lived under it. Cantos Cautivos cultivates this commonality across the wide swath of experiences presented in these two testimonies and across the entire project.

Cantos Cautivos is situated within a nexus of personal and collective memories of an era largely marked by the personal and collective trauma that continues to shape it. Furthermore, this project engages products of material and expressive culture, bringing new meaning to works through a dynamic exchange between their commemorative function in both the past and the present. We have explored here two examples of the cultural production of two individuals and the ways it shaped and continues to shape their understanding of this moment. These testimonies are singular but also dialogue with each other and the other testimonies in the archive to demonstrate dynamic possibilities that interact with "authoritative" narratives of memory and history in Chile.

\section{Bibliography}

Aguilera, Carolina, and Gonzalo Cáceres. "Signs of State Terrorism in Post-Authoritarian Santiago: Memories and Memorialization in Chile." Dissidences: Hispanic Journal of Theory and Criticism 4, no. 8 (2012): Article 7. https://digitalcommons.bowdoin.edu/dissidences/vol4/iss8/7.

Bell, Vikki. "Entwined Tellings and the Fragility of the Unique: Relating Narratives of Detention and Survival in Pinochet's Chile." Third Text32, no. 1 (2018): 125-149. https://doi.org/10.1080/09528822.2018.1459111.

Benegas, Diego. “'If There's No Justice...': Trauma and Identity in Post-Dictatorship Argentina.” Performance Research 16, no. 1 (2011): 20-30. https://doi.org/10.1080/13528165.2011.561671.

Carrasco, Eduardo. La Nueva Canción en América Latina. Santiago: CENECA, 1982.

Cattell, Maria G., and Jacob J. Climo. "Introduction: Meaning in Social Memory and History: Anthropological Perspectives." In Social Memory and History: Anthropological Perspectives, edited by Jacob J. Climo and Maria G. Cattell, 1-36. Walnut Creek, CA: Altamira Press, 2002.

Cifuentes Seves, Luis. Dilo, antes que sea demasiado tarde. Santiago: Editorial Cuarto Propio, 2020.

\footnotetext{
${ }^{40}$ Andrew Flinn, Mary Stevens, and Elizabeth Shepard, "Whose memories, whose archives? Independent community archives, autonomy and the mainstream," Archival Science 9, no. 1/2 (2009): 75. Cited in Drake, "Seismic Shifts."
} 
Chornik, Katia. "Music and Torture in Chilean Detention Centers: Conversations with an Ex-Agent of Pinochet's Secret Police. The World of Music 2, no. 1 (2013): 51-56.

Chornik, Katia. "Memories of Music in Political Detention in Chile under Pinochet." Journal of Latin American Cultural Studies 27, no. 2 (2013): 157-173. https://doi.org/10.1080/13569325.2018.1450742.

Comisión Nacional Sobre Prisión Política y Tortura. Informe de la Comisión Nacional sobre Prisión Política y Tortura. 2004. https://doi.org/10.38178/cep.vi97.642.

Davidson, Caroline. "Nunca más meets \#niunamenos-Accountability for Pinochet-era Sexual Violence in Chile." Columbia Human Rights Law Review 51, no. 1 2019: 100-182.

Drake, Jarrett M. “Seismic Shifts: On Archival Fact and Fictions.” Medium, August 20, 2018. https://medium.com/community-archives/seismic-shifts-on-archival-fact-and-fictions$\underline{6 \mathrm{db} 4 \mathrm{~d} 5 \mathrm{c} 655 \mathrm{ae}}$.

Fairley, Jan. "La Nueva Canción Latinoamericana." Bulletin of Latin American Research 3, no. 2 (1984): 107-115. https://doi.org/10.2307/3338257.

González, Juan Pablo, Oscar Ohlsen, and Claudio Rolle. Historia Social de la Música Popular en Chile, 1950-1970. Santiago: Ediciones Universidad Católica de Chile, 2009.

Hite, Katherine, and Cath Collins. "Memorial Fragments, Monumental Silences and Reawakenings in 21st-century Chile.” Millennium: Journal of International Studies 38, no. 2 (2009): 379-400. https://doi.org/10.1177/0305829809347537.

Jelin, Elizabeth. State Repression and the Labors of Memory. Translated by Judy Rein and Marcial GodoyAnativa. Minneapolis: University of Minnesota Press, 2003.

Jordán González, Laura. "Chilean New Song's cueca larga." In The Militant Song Movement in Latin America: Chile, Uruguay, and Argentina, edited by Pablo Vila, 71-96. Plymouth, UK: Lexington Books, 2014.

Kornbluh, Peter. "Letter from Chile." The Nation. January 13, 2005. https://archive.globalpolicy.org/intljustice/wanted/2005/0113chileletter.htm.

Lazzara, Michael J. Chile in Transition: The Poetics and Politics of Memory. Gainesville: University of Florida Press, 2006.

Lazzara, Michael J. Civil Obedience: Complicity and Complacency in Chile since Pinochet. Madison: University of Wisconsin Press, 2018.

McSherry, Patrice. "The Political Impact of Chilean New Song in Exile." Latin American Perspectives 44, no. 5 (2016): 13-29. https://doi.org/10.1177/0094582X16683374.

Mamdani, Mahmood. "Amnesty or Impunity? A Preliminary Critique of the Report of the Truth and Reconciliation Commission of South Africa (TRC)." Diacritics 32, nos. 3/4 (2002): 32-59. https://doi.org/10.1353/dia.2005.0005.

Montealegre Iturra, Jorge. Derecho a Fuga: Una extraña felicidad compartida. 2nd ed. Santiago: Editorial Asterión, 2018.

Moon, Claire. "Healing Past Violence: Traumatic Assumptions and Therapeutic Interventions in War and Reconciliation." Journal of Human Rights 8, no. 1 (2009): 71-91. https://doi.org/10.1080/14754830902717726.

Museo de la Memoria. "Sobre el museo." https://web.museodelamemoria.cl/sobre-el-museo/\#menu6.

Nora, Pierre. "Between Memory and History: Les Lieux de Mémoire.” Representations 26 (Spring 1989): 7-24. https://doi.org/10.2307/2928520. 
Pollak, Michael. "Memoria, olvido, silencio.” In Memoria, Olvido, Silencio: La producción social de identidades frente a situaciones límite, translated by Christian Gebauer, Renata Olveira Rufino, and Mariana Tello; edited by Ludmila da Silva Catela, 17-32. Buenos Aires: Ediciones al Margen, 2006.

Read, Peter, and Marivic Wyndham. Narrow but Endlessly Deep: The Struggle for Memorialisation in Chile since the Transition to Democracy. Acton, ACT: Australian National University Press, 2016. https://doi.org/10.22459/NBED.06.2016.

Stern, Steve J. Reckoning with Pinochet: The Memory Question in Democratic Chile, 1989-2006. Durham, NC: Duke University Press, 2010. https://doi.org/10.1215/9780822391777.

Taylor, Diana. The Archive and the Repertoire. Durham, NC: Duke University Press, 2003.

Taylor, Diana. Villa Grimaldi. http://villagrimaldi.typefold.com.

Tesche Roa, Paula, and Javier González Alacarón. "Resistencia política en la oficina salitrera de Chacabuco (1973-1975), región de Antofagasta, Chile.” Historia y Memoria 19 (2019): 309-344. https://doi.org/10.19053/20275137.n19.2019.9200.

Traverso, Antonio. "Dictatorship Memories: Working through Trauma in Chilean Post-Dictatorship Documentary." Continuum 24, no. 1 (2010): 179-191. https://doi.org/10.1080/10304310903444037.

United States Institute of Peace. "Commission of Inquiry: Chile 03." https://www.usip.org/publications/2003/09/commission-inquiry-chile-03

Vesely, Sergio. "A Finger-Picked Cueca from a Solidary Companion.” Cantos Cautivos, September 23, 2015, https://www.cantoscautivos.org/en/testimony.php?query=10752. 